\title{
Inhibition of tuber sprouting in potato cultivars Asterix and Challenger by 1.4-dimethylnaphthalene
}

\author{
Abelardo Barreto de Mendonça Neto ${ }^{1}$ (D) Ariana Mota Pereira ${ }^{1}$ (D) \\ Maria Eduarda da Silva Guimarães ${ }^{1^{*}}$ (D) Dreice Nascimento Gonçalves ${ }^{1}$ (iD \\ Luciana Gomes Soares ${ }^{2}$ Renata Ranielly Pedroza Cruz ${ }^{1}(\mathbb{D})$ Ana Izabella Freire ${ }^{1}(\mathbb{D}$ \\ Fernando Luiz Finger $^{1}$ (D) Paulo Roberto Cecon $^{3}(\mathbb{D})$
}

\author{
${ }^{1}$ Departamento de Agronomia, Universidade Federal de Viçosa (UFV), 36570-900, Viçosa, MG, Brasil. E-mail: maria.eduarda.ufv@gmail.com. \\ "Corresponding author. \\ ${ }^{2}$ Departamento de Biologia Vegetal, Universidade Federal de Viçosa (UFV), Viçosa, MG, Brasil. \\ ${ }^{3}$ Departamento de Estatística, Universidade Federal de Viçosa (UFV), Viçosa, MG, Brasil.
}

ABSTRACT: The aim of this study was to verify the efficiency of 1,4-dimethylnapthalene in suppressing sprouting and the consequent maintenance of the quality of potato tubers of Asterix and Challenger cultivars, at different temperatures and storage regimes. Six treatments were tested, with and without 1.4-DNM, at temperatures of $8^{\circ} \mathrm{C}$ and $20^{\circ} \mathrm{C}$. Assessments were made at 0, 45, 90,135 and 180 days after application. The parameters evaluated were: number of sprouts, levels of total soluble sugars, levels of reducing and non-reducing sugars and coloration of potato strips after frying. The effects of 1.4-DMN on the quality control of potatoes resulted in sprout control and lower levels of total soluble sugars and reducing sugars, especially in the Challenger cultivar and at a temperature of $20^{\circ} \mathrm{C}$.

Key words: stored potatoes, quality maintenance, sprout suppressor.

Inibição da brotação dos tubérculos das cultivares de batata Asterix e Challenger pelo 1,4-dimetilnaftaleno

RESUMO: Objetivou-se com este estudo verificar a eficiência do 1,4-dimetilnaftaleno na supressão da brotação e a consequente manutenção da qualidade de tubérculos de batata das cultivares Asterix e Challenger, em diferentes temperaturas e tempos de armazenamento. Foram testados seis tratamentos, com e sem 1,4-DNM, nas temperaturas de $8^{\circ} \mathrm{Ce} 20^{\circ} \mathrm{C}$. As avaliações foram feitas aos 0, 45, 90, 135 e 180 dias após a aplicação. Os parâmetros avaliados foram: número de brotos, teores de açúcares solúveis totais, teores de açúcares redutores, e não redutores, e coloração dos palitos de batata após a fritura. Os efeitos do 1,4-DMN no controle da qualidade das batatas resultaram no controle da brotação e em menores teores de açúcares solúveis totais e de açúcares redutores, sobretudo na cultivar Challenger e à temperatura de $20{ }^{\circ} \mathrm{C}$.

Palavras-chave: batatas armazenadas, manutenção da qualidade, supressor da brotação.

\section{INTRODUCTION}

The potato is an important commodity in the world, being one of the most consumed foods, due to the diversity of forms of preparation and nutritional composition. The consumption of processed potatoes has been growing, due to changes in eating habits and the ease of semi-finished foods (FREITAS et al., 2006). Therefore, there was a need for cultivars with storage potential to supply the production chain throughout the year.

In order to prolong the storage period, the tubers are refrigerated. However, the temperature used in the refrigeration chambers should reduce sprouting, respiratory activity and the occurrence of diseases, without promoting the accumulation of sugars in the tubers, which can lead to loss of quality in processing.

Sprouting despite refrigeration is not completely inhibited and remains a problem for industry, as it causes an increase in respiratory rate, loss of water through transpiration and an increase in the conversion of starch into reducing sugars, glucose and fructose (SINGH \& KAUR, 2016). These physiological changes reduce the potential for storage and may promote the occurrence of the Maillard reaction during frying, which causes the fries to darken.

To avoid these problems, sprout suppressors such as chloropropane (CIPC) are 
used (BLENKINSOP et al., 2002). This suppressor was widely used in the United States and in European countries, however, its use has suffered some limitations due to the possible accumulation of substances toxic to man and the environment (VIJAY et al., 2016). In Brazil, the use of CIPC is not registered. Therefore, several studies have been looking for alternatives to the use of CIPC. Among them we can mention 1.4-dimethylnaphthalene (1.4$\mathrm{DMN}$ ), which is a product of low environmental risk and human health, and can be used in stored potatoes (WEERD et al., 2010). Thus, the objective of this study was to determine the efficiency of the use of 1,4DMN in suppressing sprouting and the consequent maintenance of the quality of potato tubers of Asterix and Challenger cultivars, at different temperatures and storage regimes.

\section{MATERIALS AND METHODS}

\section{Experimental design and area characterization}

The experiment was carried out in Split-plot, with the treatments in the plots (Ast/ Control $/ 8{ }^{\circ} \mathrm{C}$; Ast $/ 1.4-\mathrm{DMN} / 8^{\circ} \mathrm{C}$; Ast/Control $/ 20{ }^{\circ} \mathrm{C}$; Ast/1.4-DMN/20 ${ }^{\circ} \mathrm{C}$; Cha/Control $/ 8{ }^{\circ} \mathrm{C}$; Cha/1.4$\mathrm{DMN} /{ }^{\circ} \mathrm{C}$; $\mathrm{Cha} / \mathrm{Control} / 20{ }^{\circ} \mathrm{C}$; $\mathrm{Cha} / 1.4-\mathrm{DMN} / 20{ }^{\circ} \mathrm{C}$ ) and in the subplots the evaluation times $(0,45$, 90, 135 and 180 days), in the Fully Randomized Design with 4 repetitions. The potato tubers of the Asterix and Challenger cultivars came from the production area of Perdizes-MG (19 $21^{\circ}$ ' 10 "S and $47^{\circ} 17$ ' 34" W, altitude of $1000 \mathrm{~m}, \mathrm{Cwb}$ classification according to Köppen and Geiger, characterized by rainy summer and winter dry). The tubers were planted in March and harvested in July 2017 and subsequently selected for the absence of mechanical damage, deformations and weight ranging from $90 \mathrm{~g}$ and $250 \mathrm{~g}$.

\section{Experimental procedure and analyses}

The treatments were formed by $20 \mu \mathrm{l}$ of 1.4-dimethylnaphthalene (1.4-DMN) (sigma) diluted in $15 \mathrm{ml}$ of $95 \%$ alcohol (WEERD et al., 2010), applied on filter paper and placed in a petri dish heated for complete volatilization for 30 minutes inside hermetically sealed buckets containing 1 kilo of potato. The control consisted of $15 \mathrm{ml}$ of $95 \%$ alcohol. After applying the treatments, the tubers were removed from the buckets and stored in incubators (BOD's), under temperatures of $8{ }^{\circ} \mathrm{C}$ and $20{ }^{\circ} \mathrm{C}$ and relative humidity of $85-90 \%$ in the absence of light. The analyzes were performed at $0,45,90,135$ and 180 days after application of the treatments. The parameters evaluated were number of sprouts (determined by visual counting), total soluble sugar (TSS) content, reducing (RS) and non-reducing (N-RS) sugar content and color of the potato strips after frying.

\section{Total soluble sugars}

TSS quantification followed the Phenolsulfuric method (DUBOIS et al., 1956), where the curve was calibrated, based on the standard $1 \%$ sucrose solution. Aliquots of $250 \mu \mathrm{L}$ of the samples were pipetted into a glass tube, plus $250 \mu \mathrm{L}$ of $5 \%$ phenol, and $1.25 \mathrm{~mL}$ of concentrated sulfuric acid. The material was in a thermostatic bath at $30{ }^{\circ} \mathrm{C}$ for 20 minutes. The reading was performed on a spectrophotometer, with a wavelength $(\lambda)$ of $490 \mathrm{~nm}$. The result was expressed in $\%$ TSS.

\section{Reducing and non-reducing sugars}

The determination of RS was performed according to the Somogy-Nelson methodology (NELSON, 1944), where the curve was calibrated, based on the standard $1 \%$ glucose solution. 200 $\mu \mathrm{L}$ aliquots of the sample were added to $200 \mu \mathrm{L}$ of Nelson's reagent. The material was left for 15 minutes in boiling water followed by cooling in water. $200 \mu \mathrm{L}$ of the arsenomolybdic solution and $600 \mu \mathrm{L}$ of water were added. The readings were performed on a spectrophotometer, with a wavelength $(\lambda)$ of $540 \mathrm{\eta m}$ and the result was expressed in $\%$ RS. The quantification of N-RS was determined from the difference in TSS and RS content, expressed in $\%$ N-RS.

\section{Coloring of potato strips after frying}

The stored tubers were peeled, sliced into strips and fried in an electric fryer. The frying of the potatoes was carried out at $180^{\circ} \mathrm{C}$ for 3 minutes. The color of the French fries was determined visually, by comparison, following the scale of notes determined by the United States Department of Agriculture (USDA, 1967) and the Brazilian potato industry whose color scale ranges from 1 (lighter) to 5 (darker).

\section{Data analysis}

The data obtained were analyzed using analysis of variance and regression using the System of Statistical and Genetic Analysis (SAEG, 2007), and the means compared by the Tukey test $(\mathrm{P} \leq 0.05)$. The regression model was chosen according to the significance of the regression coefficients, using the $t$ test $(\mathrm{P} \leq 0.05)$ and the determination coefficient ( $\mathrm{R} 2$ $=$ SQReg / SQtrat). 


\section{RESULTS AND DISCUSSION}

The lowest storage temperature $\left(8^{\circ} \mathrm{C}\right)$ and the application of 1.4-DMN did not cause a reduction in the number of sprouts of the Asterix cultivar in any of the evaluation periods (Table 1). However, in the Challenger cultivar there was a reduction in the number of sprouts with the reduction of temperature and with the application of 1.4-DMN at 135 and 180 days of storage (Table 1). Indicating that the effect of temperature and sprout suppressor varies with the cultivar. The mode of action of 1.4-DMN is not yet clearly understood, but it has been suggested that the natural dormancy period is extended through the regulation of phytohormones (CAMPBELL et al., 2010).

The number of sprouts increased with the storage time in both cultivars (Figures 1A and 1B), which was expected for this characteristic. However, this increase was small compared to the extended storage period (180 days) (Figures $1 \mathrm{~A}$ and $1 \mathrm{~B})$. In the Asterix cultivar, the average was 8 sprouts per tuber (Figure 1A). Whereas in the 'Challenger' the average was 5 sprouts per tuber, with the exception of the control at $20^{\circ} \mathrm{C}$, in which the average was around 25 sprouts (Figure 1B). The increase in the number of sprouts is accompanied by metabolic changes, including increased respiration, loss of mass, remobilization of starch and increase in the content of soluble sugars (FERREIRA et al., 2017).

In the Challenger cultivar, higher levels of TSS were observed in the tubers at $8{ }^{\circ} \mathrm{C}$ at 135 and 180 days (Table 2). This temperature was sufficient to induce the accumulation of sugars in this cultivar. When potato tubers are exposed to low temperatures, there is a reduction in the starch pool, due to the inhibition of their synthesis enzymes, such as AGPase and GBSS and increased transcription of the b-amylase genes, promoting starch degradation in sucrose (N-RS) which is broken down into glucose and fructose (RS) by vacuolar acid invertase in potato tubers (WIBERLEY-BRADFORD et al., 2016). TSS being the sum of these sugars.

Lower TSS levels were found in the tubers of the Challenger cultivar treated with 1.4DMN at $8{ }^{\circ} \mathrm{C}$ for 45 days and at $20{ }^{\circ} \mathrm{C}$ for 180 days (Table 2). While, in the Asterix cultivar, the tubers treated with the inhibitor had lower TSS content at 135 days at $8{ }^{\circ} \mathrm{C}$ and at 180 days at $20^{\circ} \mathrm{C}$, showing a beneficial effect of 1.4-DMN in reducing soluble sugar levels (Table 2).

For the Asterix cultivar, it was found that the lowest storage temperature $\left(8^{\circ} \mathrm{C}\right)$ resulted in higher levels of RS in most of the periods evaluated, in both conditions of use or not of 1.4DMN (Table 2). For the Challenger cultivar, this effect was less evident, with a significant effect only observed in the absence of 1.4-DMN at 45 days (Table 2). There was no effect of the use of 1.4-DMN on the RS levels in the Asterix cultivar. For the Challenger cultivar, the only difference was at 45 days with storage at $8{ }^{\circ} \mathrm{C}$, under these conditions the use of 1.4-DMN resulted in a lower mean of RS (Table 2).

Table 1 - Medium values for the sprouts number in Asterix (Ast) and Challenger (Cha) cultivars potato tubers.

\begin{tabular}{llllc}
\hline & & & \\
& & & \\
\hline
\end{tabular}

Means followed by the same letter, in the same column, do not differ at $5 \%$ probability by the Turkey test. 


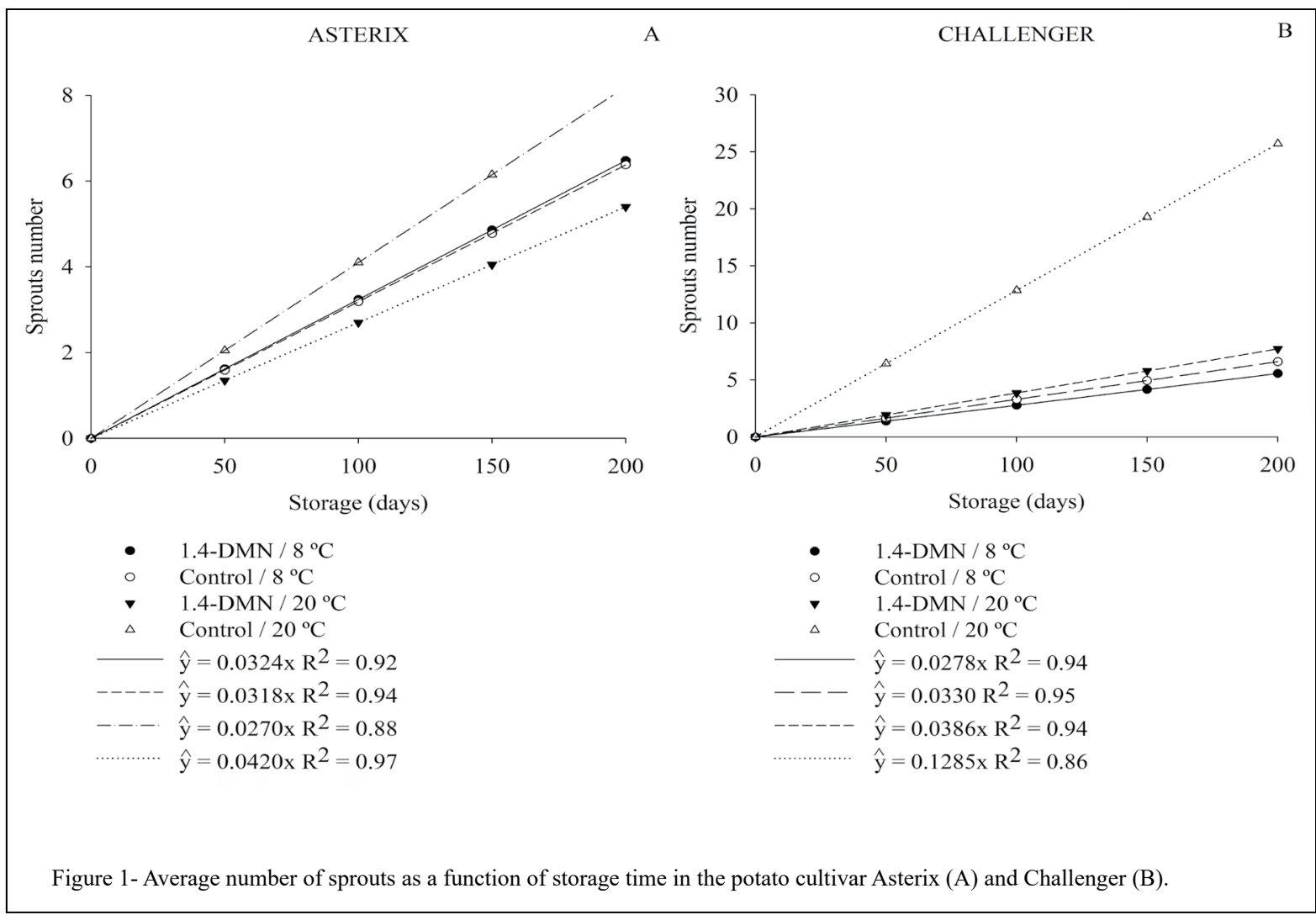

Significant effects of storage temperature on N-RS levels were only observed in the last evaluation period (180 days) for both cultivars. For the Asterix cultivar, higher averages were observed in the treatment with application of 1.4-DMN at 20 ${ }^{\circ} \mathrm{C}$. While the Challenger cultivar showed higher averages for $\mathrm{N}-\mathrm{RS}$ in the control treatment at 20 ${ }^{\circ} \mathrm{C}$ (Table 2). In the Asterix cultivar, a higher N-RS content was observed with the use of 1.4-DMN at $20{ }^{\circ} \mathrm{C}$ and at 180 days. In the 'Challenger', a higher N-RS content was obtained in the absence of 1.4DMN (Table 2). Factors such as temperature, storage time, cultivar, degree of tuber maturation and sprout growth, can influence sugar levels due to the occurrence of carbohydrate catabolism and / or enzyme activities, which reduce the amounts of starch and increase in sugars (SINGH \& KAUR., 2016).

Both cultivars showed, after frying on day zero, scale 2 (USDA) darkening. Coloring is an important quality aspect of potato chip processing. During the hydrolysis of the starch, part of the sugar produced can be used to respiration the tuber before the frying process. Depending on storage conditions, such as at low temperatures, the phenomenon of sweetening occurs, which consists of the formation and accumulation of reducing sugars, glucose and fructose, which are undesirable (SINGH \& KAUR, 2016).

During frying, a high temperature condition, the contact of reducing sugars with free amino acids and the undesirable Maillard reaction may occur. This reaction causes the formation of melanoidins, pigments that result in brownish brown fries. In addition to the depreciation of the visual aspect, there is the accumulation of acrylamide, a compound related to the development of cancer (WIBERLEYBRADFORD et al., 2016).

For the Asterix cultivar, the presence of 1.4-DMN was efficient in maintaining the visual 
Table 2 - Total soluble sugars (TSS), Reducing sugars (RS) and Non-reducing sugars (N-RS) in Asterix (Ast) and Challenger (Cha) cultivars potato tubers.

\begin{tabular}{|c|c|c|c|c|c|}
\hline Treatment & 0 day & 45 days & 90 days & 135 days & 180 days \\
\hline $1-$ Ast $/ 1,4-\mathrm{DMN} / 8{ }^{\circ} \mathrm{C}$ & $0.102 \mathrm{~A}$ & $0.301 \mathrm{ABC}$ & $0.518 \mathrm{~A}$ & $0.372 \mathrm{BC}$ & $0.513 \mathrm{BC}$ \\
\hline 2-Ast $/$ Control $/ 8^{\circ} \mathrm{C}$ & $0.088 \mathrm{~A}$ & $0.376 \mathrm{AB}$ & $0.427 \mathrm{AB}$ & $0.636 \mathrm{~A}$ & $0.533 \mathrm{BC}$ \\
\hline 3-Ast $/ 1,4-\mathrm{DMN} / 20^{\circ} \mathrm{C}$ & $0.099 \mathrm{~A}$ & $0.137 \mathrm{BC}$ & $0.217 \mathrm{BC}$ & $0.202 \mathrm{BC}$ & $0.732 \mathrm{~B}$ \\
\hline 4-Ast/Control $/ 20{ }^{\circ} \mathrm{C}$ & $0.078 \mathrm{~A}$ & $0.203 \mathrm{ABC}$ & $0.244 \mathrm{BC}$ & $0.338 \mathrm{BC}$ & $0.420 \mathrm{CD}$ \\
\hline 5-Cha/1,4-DMN $/ 8^{\circ} \mathrm{C}$ & $0.123 \mathrm{~A}$ & $0.137 \mathrm{BC}$ & $0.233 \mathrm{BC}$ & $0.263 \mathrm{BC}$ & $0.179 \mathrm{DE}$ \\
\hline $6-\mathrm{Cha} / \mathrm{Control} / 8^{\circ} \mathrm{C}$ & $0.080 \mathrm{~A}$ & $0.452 \mathrm{~A}$ & $0.331 \mathrm{ABC}$ & $0.433 \mathrm{AB}$ & $0.159 \mathrm{E}$ \\
\hline 7-Cha/1,4-DMN $/ 20^{\circ} \mathrm{C}$ & $0.121 \mathrm{~A}$ & $0.109 \mathrm{C}$ & $0.191 \mathrm{BC}$ & $0.169 \mathrm{C}$ & $0.519 \mathrm{BC}$ \\
\hline 8-Cha/Control $/ 20{ }^{\circ} \mathrm{C}$ & $0.081 \mathrm{~A}$ & $0.130 \mathrm{BC}$ & $0.170 \mathrm{C}$ & $0.174 \mathrm{C}$ & $1.007 \mathrm{~A}$ \\
\hline \multicolumn{6}{|c|}{ - } \\
\hline Treatment & 0 day & 45 days & 90 days & 135 days & 180 days \\
\hline $1-\mathrm{Ast} / 1,4-\mathrm{DMN} / 8^{\circ} \mathrm{C}$ & $0.031 \mathrm{~A}$ & $0.253 \mathrm{~A}$ & $0.385 \mathrm{~A}$ & $0.275 \mathrm{AB}$ & $0.266 \mathrm{AB}$ \\
\hline 2-Ast/Control $/ 8{ }^{\circ} \mathrm{C}$ & $0.032 \mathrm{~A}$ & $0.324 \mathrm{~A}$ & $0.248 \mathrm{AB}$ & $0.384 \mathrm{~A}$ & $0.359 \mathrm{~A}$ \\
\hline $3-\mathrm{Ast} / 1,4-\mathrm{DMN} / 20^{\circ} \mathrm{C}$ & $0.030 \mathrm{~A}$ & $0.077 \mathrm{~B}$ & $0.111 \mathrm{BC}$ & $0.097 \mathrm{C}$ & $0.221 \mathrm{ABC}$ \\
\hline 4-Ast/Control $/ 20^{\circ} \mathrm{C}$ & $0.032 \mathrm{~A}$ & $0.081 \mathrm{~B}$ & $0.083 \mathrm{C}$ & $0.125 \mathrm{BC}$ & $0.177 \mathrm{BCD}$ \\
\hline 5-Cha/1,4-DMN $/ 8^{\circ} \mathrm{C}$ & $0.032 \mathrm{~A}$ & $0.056 \mathrm{~B}$ & $0.106 \mathrm{BC}$ & $0.058 \mathrm{C}$ & $0.083 \mathrm{CD}$ \\
\hline 6-Cha/Control $/ 8^{\circ} \mathrm{C}$ & $0.028 \mathrm{~A}$ & $0.242 \mathrm{~A}$ & $0.155 \mathrm{BC}$ & $0.155 \mathrm{BC}$ & $0.038 \mathrm{D}$ \\
\hline 7-Cha/1,4-DMN $/ 20^{\circ} \mathrm{C}$ & $0.032 \mathrm{~A}$ & $0.041 \mathrm{~B}$ & $0.027 \mathrm{C}$ & $0.042 \mathrm{C}$ & $0.062 \mathrm{D}$ \\
\hline 8 -Cha/Control $/ 20^{\circ} \mathrm{C}$ & $0.029 \mathrm{~A}$ & $0.027 \mathrm{~B}$ & $0.030 \mathrm{C}$ & $0.063 \mathrm{C}$ & $0.112 \mathrm{BCD}$ \\
\hline \multicolumn{6}{|c|}{ 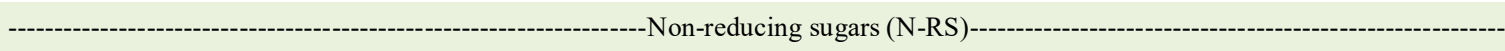 } \\
\hline Treatment & 0 day & 45 days & 90 days & 135 days & 180 days \\
\hline $1-\mathrm{Ast} / 1,4-\mathrm{DMN} / 8^{\circ} \mathrm{C}$ & $0.070 \mathrm{~A}$ & $0.047 \mathrm{~A}$ & $0.133 \mathrm{~A}$ & $0.108 \mathrm{~A}$ & $0.247 \mathrm{C}$ \\
\hline 2-Ast/Control $/ 8^{\circ} \mathrm{C}$ & $0.055 \mathrm{~A}$ & $0.052 \mathrm{~A}$ & $0.179 \mathrm{~A}$ & $0.251 \mathrm{~A}$ & $0.173 \mathrm{C}$ \\
\hline $3-\mathrm{Ast} / 1,4-\mathrm{DMN} / 20{ }^{\circ} \mathrm{C}$ & $0.069 \mathrm{~A}$ & $0.060 \mathrm{~A}$ & $0.106 \mathrm{~A}$ & $0.104 \mathrm{~A}$ & $0.510 \mathrm{~B}$ \\
\hline 4-Ast/Control $/ 20^{\circ} \mathrm{C}$ & $0.046 \mathrm{~A}$ & $0.121 \mathrm{~A}$ & $0.160 \mathrm{~A}$ & $0.212 \mathrm{~A}$ & $0.243 \mathrm{C}$ \\
\hline 5-Cha/1,4-DMN/8 ${ }^{\circ} \mathrm{C}$ & $0.090 \mathrm{~A}$ & $0.081 \mathrm{~A}$ & $0.127 \mathrm{~A}$ & $0.204 \mathrm{~A}$ & $0.096 \mathrm{C}$ \\
\hline 6-Cha/Control $/ 8^{\circ} \mathrm{C}$ & $0.051 \mathrm{~A}$ & $0.209 \mathrm{~A}$ & $0.175 \mathrm{~A}$ & $0.278 \mathrm{~A}$ & $0.121 \mathrm{C}$ \\
\hline 7-Cha/1,4-DMN/20 ${ }^{\circ} \mathrm{C}$ & $0.088 \mathrm{~A}$ & $0.068 \mathrm{~A}$ & $0.164 \mathrm{~A}$ & $0.126 \mathrm{~A}$ & $0.457 \mathrm{~B}$ \\
\hline 8-Cha/Control $/ 20^{\circ} \mathrm{C}$ & $0.051 \mathrm{~A}$ & $0.103 \mathrm{~A}$ & $0.140 \mathrm{~A}$ & $0.111 \mathrm{~A}$ & $0.895 \mathrm{~A}$ \\
\hline
\end{tabular}

Means followed by the same letter, in the same column, do not differ at $5 \%$ probability by the Turkey test.

appearance of the fries, at $20^{\circ} \mathrm{C}$, in the periods of 45, 90 and 135 days (Figure 2). Whereas, for the cultivar Challenger, the presence of $1.4-\mathrm{DMN}, 8^{\circ} \mathrm{C}$, was efficient in reducing the reducing sugar levels (Figure 2), for the period of 45 days, which gives better quality to the potatoes after frying, in relation to their respective control.

\section{CONCLUSION}

The application of 1.4-DMN does not control the sprouting of stored tubers of cultivar Asterix. In cultivar Challenger, the application of 1.4-DMN controls sprouting and reduces the levels of total soluble sugars and reducing sugars at a temperature of $20^{\circ} \mathrm{C}$. 


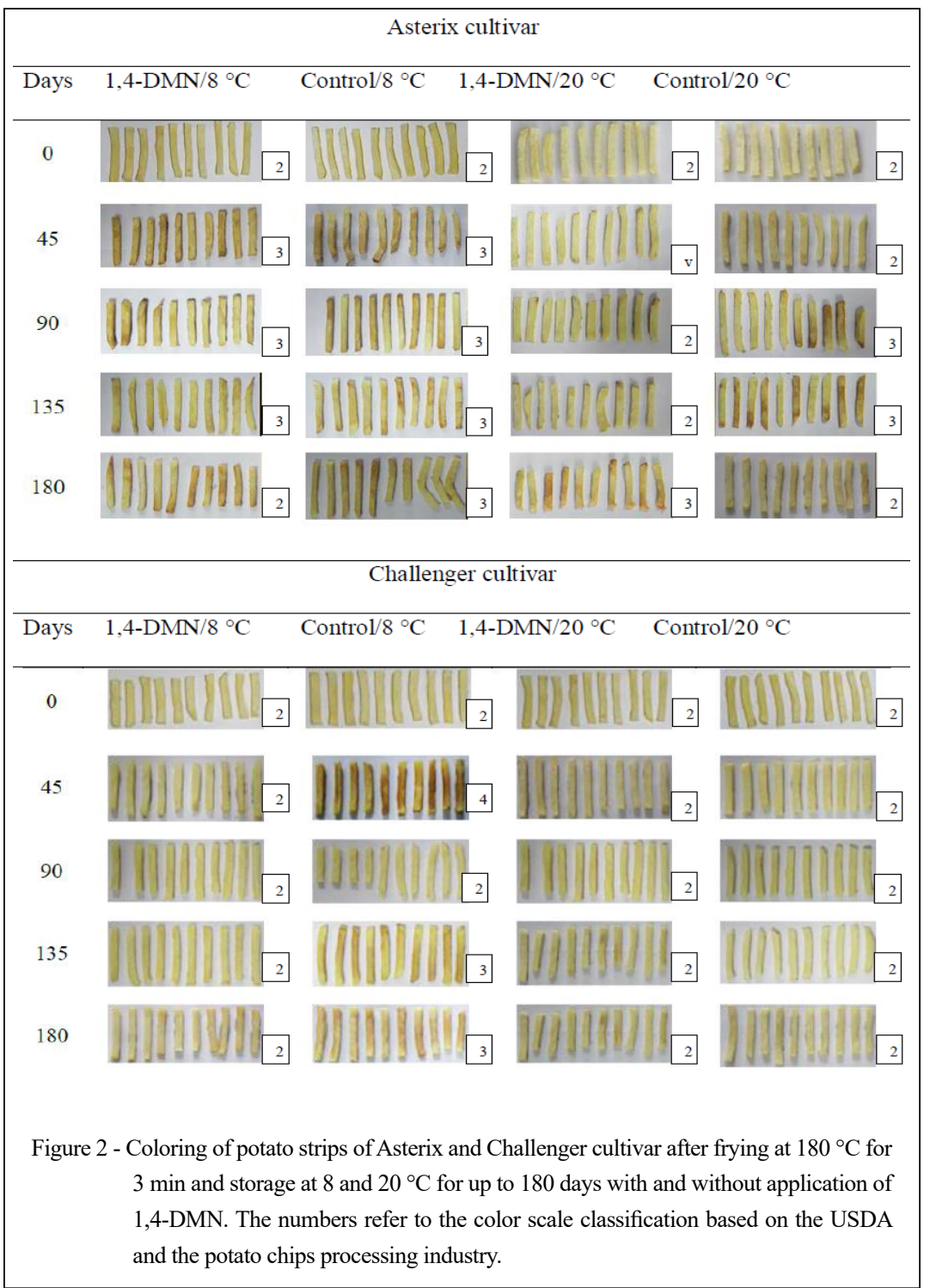

\section{ACKNOWLEDGEMENTS}

The authors thank Fundação de Amparo à Pesquisa de Minas Gerais (FAPEMIG), Conselho Nacional de Desenvolvimento Científico e Tecnológico (CNPq) and Coordenação de Aperfeiçoamento de Pessoal de Nível Superior (CAPES).

\section{DECLARATION OF CONFLICT OF INTEREST}

The authors declare no conflict of interest. The founding sponsors had no role in the design of the study; in the collection, analyses, or interpretation of data; in the writing of the manuscript, and in the decision to publish the results.

\section{AUTHORS' CONTRIBUTIONS}

All authors contributed equally for the conception and writing of the manuscript. All authors critically revised the manuscript and approved of the final version.

\section{REFERENCES}

BLENKINSOP, R. et al. Changes in compositional parameters of tubers of Potato (Solanum tuberosum) during Low-Temperature Storage and Their Relationship to Chip Processing Quality. 
Journal of Agricultural and Food Chemistry, v. 50, n. 16, p.4545-4553, 2002. Available from: <https://pubs.acs.org/doi/ pdf/10.1021/jf0255984>. Accessed: Feb. 15, 2021. doi: 10.1021/ jf0255984.

CAMPBELL, M.A. et al. The sprout inhibitors chlorpropham and 1,4-dimethylnaphthalene elicit different transcriptional profiles and do not suppress growth through a prolongation of the dormant state. Plant molecular biology, v. 73, n. 1, p.181189, 2010. Available from: <file://C:/Users/USER/Downloads/ Campbel12010 Article TheSproutInhibitorsChlorpropha\%20(1). pdf $>$. Accessed: Feb. 15, 2021. doi: 10.1007/s11103-010-9607-6.

DUBOIS, M. etal.Colorimetric method form determination of sugars and related substaceas. Analytical Chemistry, v. 28, n. 3, p.350356, 1956. Available from: <file://C:/Users/USER/Downloads/ rometricMethodforDeterminationofSugarsandRelatedSubstances. pdf $>$. Accessed: Feb. 15, 2021. doi: 10.1021/ac60111a017.

FERREIRA, S.J. et al. Simultaneous silencing of isoamylases ISA1, ISA2 and ISA3 by multi-target RNAi in potato tubers leads to decreased starch content and an early sprouting phenotype. PLoS One, v. 12, n. 7, p. e0181444, 2017. Available from: $<$ https://journals.plos.org/plosone/article?id=10.1371/journal pone.0181444>. Accessed: Feb. 15, 2021. doi: 10.1371/journal. pone. 0181444

FREITAS, S.T. et al. Qualidade para processamento de clones de batata cultivados durante a primavera e outono no Rio Grande do Sul. Ciência Rural, v. 36, n. 1, p.80-85, 2006. Available from: <https://www.scielo.br/scielo.php?pid=S0103$84782006000100012 \&$ script $=$ sci_arttext\&tlng=pt $>$. Accessed: Feb. 15, 2021. doi: 10.1590/S0103-84782006000100012.

NELSON, N.A. A fhotometric adaption of the Somogyi method for the determination of glucose. Journal of Biological Chemistry, v. 153, n. 2, p.375-380, 1944 Available from: <file://C:/Users/USER/Downloads/
OTOMETRICADAPTATIONOFTHESOMOGYIMETHOD $\% 20$ (1).pdf $>$. Accessed: Feb. 15, 2021. doi: 10.1016/s00219258(18)71980-7.

SAEG - Sistema para análises estatísticas, versão 9.1: Fundação Arthur Bernardes - UFV -Viçosa. 2007. Available from: <http:// arquivo.ufv.br/saeg/>. Accessed: Feb. 15, 2021.

SINGH, J.; KAUR, L. Advances in potato chemistry and technology. London: New Academic press, 2016. 2v.

UNITED STATES DEPARTMENT OF AGRICULTURE - USDA. United States Standands for Grades of Frozen French Fried Potato. Baltimore, 16p., 1967.

VIJAY, P. et al. Sprout suppression on potato: need to look beyond CIPC for more effective and safer alternatives. Journal of food science and technology, v. 53 , n. 1, p. 1-18, 2016. Available from: $\quad<$ file:///C:/Users/USER/Downloads/Paul2016_Article SproutSuppressionOnPotatoNeedT.pdf $>$ Accessed: Feb. 15, 2021. doi: 10.1007/s13197-015-1980-3.

WEERD, J.W. et al. Sprout suppressing residue levels of 1, 4-dimethylnaphthalene $(1,4-1,4-\mathrm{DMN})$ in potato cultivars. American journal of potato research, v. 87, n. 5, p. 434-445, 2010. Available from: <file:///C:/Users/USER/Downloads/ Weerd2010_Article_SproutSuppressingResidueLevels.pdf $>$. Accessed: Feb. 15, 2021. doi: 10.1007/s12230-010-9146-3.

WIBERLEY-BRADFORD, A. E. et al. Temperaturedependent regulation of sugar metabolism in wild-type and low-invertase transgenic chipping potatoes during and after cooling for low-temperature storage. Postharvest Biology and Technology, v. 115, p.60-71, 2016. Available from: $\quad<$ https://bethke.horticulture.wisc.edu/wp-content/ uploads/sites/26/2020/01/877DC3E3-D2D1-4434-9FD7BCEDA2A021C8.pdf $>$. Accessed: Feb. 15, 2021. doi: 10.1016/j.postharvbio.2015.12.020. 